\title{
Hipertensi Krisis pada Anak
}

\author{
Sudung O. Pardede \\ Departmen Ilmu Kesehatan Anak, FKUI-RSCM Jakarta
}

\begin{abstract}
Hipertensi krisis adalah keadaan gawat darurat yang memerlukan penanganan segera. Hipertensi krisis dibedakan atas hipertensi emergensi dan hipertensi urgensi. Hipertensi emergensi berarti hipertensi yang disertai kerusakan organ target sedangkan hipertensi urgensi merupakan hipertensi yang tidak disertai kerusakan organ target. Umumnya hipertensi pada anak adalah hipertensi sekunder, dan penyebab hipertensi krisis yang paling sering adalah penyakit renoparenkim dan renovaskular. Hipertensi krisis terjadi melalui beberapa mekanisme antara lain melalui sistem renin angiotensin, overload cairan, stimulasi simpatetik, disfungsi endotel, dan obat-obatan. Sebagai keadaan gawat darurat, prinsip tata laksana hipertensi krisis adalah menurunkan tekanan darah secepatnya untuk mencegah kerusakan organ target. Penanganan hipertensi krisis meliputi pemberian antihipertensi onset cepat, mengatasi kelainan organ target (otak, jantung, retina), mencari dan menanggulangi penyebab hipertensi, serta terapi suportif. Antihipertensi yang sering digunakan adalah labetalol, nikardipin, natrium nitroprusid, diazoksida, hidralazin, fenoldopam, klonidin, sedangkan di Indonesia, antihipertensi yang digunakan untuk tata laksana hipertensi krisis adalah klonidin, nifedipin, natrium nitroprusid, dan nikardipin. (Sari Pediatri 2009;11(4):289-97).
\end{abstract}

Kata kunci: hipertensi krisis, hipertensi emergensi, hipertensi urgensi, antihipertensi

$\mathrm{H}$ ipertensi krisis adalah keadaan gawat darurat yang memerlukan penanganan segera untuk mencegah kerusakan organ target. Meskipun kejadiannya tidak begitu sering, tetapi keadaan ini merupakan keadaan yang berat yang dapat menyebabkan kematian. Untuk memahami pengertian hipertensi krisis, terlebih dahulu dipahami batasan hipertensi pada anak. Batasan hipertensi pada anak berbeda dengan dewasa karena

\section{Alamat korespondensi}

Dr. Sudung O. Pardede, Sp.A(K). Divisi Nefrologi. Departemen Ilmu Kesehatan Anak Fakultas Kedokteran Universitas Indonesia Jl. Salemba no. 6, Jakarta 10430. Telepon: 021-3915179. Fax.021-390 7743. tekanan darah pada anak bergantung pada berbagai faktor, termasuk umur, jenis kelamin, maupun tinggi badan. ${ }^{1,2}$

Manifestasi klinis yang tergantung pada kelainan organ target membuat manifestasi klinis hipertensi krisis tidak spesifik, kadang-kadang asimtomatik sehingga hipertensi krisis tidak terdiagnosis atau sering terlambat didiagnosis. Pengukuran tekanan darah yang tidak rutin dilakukan pada anak merupakan salah satu penyebab luputnya diagnosis hipertensi krisis. Kriteria hipertensi krisis yang sering tidak sama membuat kesulitan dalam menegakkan diagnosis. Tidak jarang hipertensi malah semakin berat karena pemberian obat-obatan tertentu misalnya pemberian steroid pada pasien yang tidak terdeteksi menderita 
hipertensi. ${ }^{2,3}$ Hipertensi krisis dapat ditandai dengan hipertensi ensefalopati, gagal jantung kongestif, gagal ginjal akut, edema paru, stroke, trauma kepala, infark miokard, atau krisis adrenergik yang dapat menyebabkan kematian. Oleh karena itu, hipertensi krisis membutuhkan penanganan yang cepat dan adekuat untuk mencegah kematian dan mencegah atau mengurangi sekuele yang dapat terjadi. Diagnosis yang terlambat dan tata laksana yang tidak adekuat dapat bersifat fatal. Banyak obat antihipertensi yang beredar di pasaran, tetapi tidak semua dapat digunakan untuk tata laksana hipertensi krisis.

Sebagai keadaan gawat dan darurat, dibutuhkan obat antihipertensi yang bekerja cepat dan aman. ${ }^{1,2}$ Meskipun banyak obat yang digunakan dalam tata laksana hipertensi krisis, tetapi hanya beberapa saja yang tersedia di negara kita.

\section{Defenisi dan klasifikasi}

Pada tahun 1987 Report of the Second Task Force on Blood Pressure Control in Children, mendefinisikan hipertensi dengan tekanan darah $>$ persentil $95^{\text {th }}$ berdasarkan umur dan jenis kelamin dengan pemeriksaan tiga kali berturut-turut, yang dapat dibagi menjadi hipertensi bermakna jika tekanan darah antara persentil $95^{\text {th }}-99^{\text {th }}$ berdasarkan umur dan jenis kelamin, dan hipertensi berat jika tekanan darah $>$ persentil $99^{\text {th }}$ berdasarkan umur dan jenis kelamin. ${ }^{4}$

National High Blood Pressure Education Program Working Group on High Blood Pressure in Children and Adolescents (2004) merevisi definisi menjadi hipertensi adalah tekanan darah sistolik atau diastolik $\geq$ persentil $95^{\text {th }}$ berdasarkan umur, jenis kelamin, dan tinggi badan pada $\geq 3$ kali pemeriksaan saat yang berbeda. Hipertensi dibagi menjadi dua stadium. Hipertensi stadium 1 adalah hipertensi dengan tekanan darah berkisar antara persentil $\geq 95^{\text {th }}$ sampai persentil $99^{\text {th }}$ plus $5 \mathrm{mmHg}$ berdasarkan umur, jenis kelamin, dan tinggi badan. Hipertensi stadium 2 adalah hipertensi dengan tekanan darah $\geq$ persentil $99^{\text {th }}$ plus $5 \mathrm{mmHg}$ berdasarkan umur, jenis kelamin, dan tinggi badan. ${ }^{5}$

Umumnya, hipertensi krisis didefinisikan jika tekanan darah diastolik $\geq 120 \mathrm{mmHg}$ dan atau tekanan darah sistolik $\geq 180 \mathrm{mmHg}$, atau setiap tingkat hipertensi yang disertai komplikasi ensefalopati hipertensi, dekompensasio kordis, atau kelainan retina berupa perdarahan atau edema papil., ${ }^{3,6}$ Pada bayi anak $<5$ tahun, didefinisikan hipertensi krisis jika tekanan darah meningkat $50 \%$ dari nilai tekanan darah normal atau $1^{1 / 2}$ kali batas atas tekanan darah normal berdasarkan umur dan jenis kelamin. ${ }^{3}$

Beberapa istilah atau klasifikasi digunakan untuk hipertensi, tetapi pembagian ini sebenarnya tidak mutlak dan tergantung pada penilaian klinik. Dari sudut pendekatan klinis untuk kemudahan dalam menentukan prioritas terapi, Joint National Committee on Detection, Evaluation, and Treatment of High Blood Pressure (1984) membagi hipertensi krisis menjadi dua kelompok yaitu hipertensi emergensi (hypertensive emergencies, hipertensi gawat) dan hipertensi urgensi (hypertensive urgencies, hipertensi darurat). ${ }^{7}$ Hipertensi emergensi diartikan dengan hipertensi yang berkaitan dengan gejala yang mengancam jiwa dan atau kerusakan organ target (otak, jantung, ginjal, mata). Keadaan ini memerlukan tindakan penurunan tekanan darah segera (bila perlu dalam 1 jam) untuk membatasi komplikasi. Termasuk hipertensi emergensi adalah hipertensi ensefalopati, gangguan intrakranial akut (perdarahan intrakranial, trombosis pembuluh darah otak, perdarahan subaraknoid, trauma kepala), sindrom iskemik miokard (gagal jantung dengan edema paru, diseksi aorta akut), gagal ginjal akut, peningkatan katekolamin (feokromositoma krisis). ${ }^{2,7}$ Hipertensi ensefalopati adalah hipertensi yang menimbulkan gangguan fungsi otak akut yang ditandai dengan penurunan kesadaran, disfungsi susunan saraf pusat, dan biasanya reversibel dengan antihipertensi. ${ }^{8-14}$

Hipertensi urgensi adalah hipertensi tanpa disertai gejala klinis atau kerusakan organ target yang bermakna, tetapi dapat progresif menjadi hipertensi emergensi. Hipertensi urgensi memerlukan penurunan tekanan darah segera dalam waktu 12 hingga 24 jam. Termasuk dalam hipertensi urgensi adalah hipertensi akselerasi (accelerated hypertension) yaitu peningkatan tekanan darah yang cepat dibandingkan keadaan hipertensi sebelumnya, hipertensi maligna, hipertensi perioperatif. ${ }^{1,2,7}$

\section{Etiologi}

Penyebab hipertensi krisis adalah semua penyebab hipertensi. Penyebab hipertensi pada anak sangat bervariasi dan tergantung pada umur. Dalam masa 
neonatus, 2/3 hipertensi disebabkan oleh trombosis renovaskular (spontan atau berkaitan dengan asfiksia, penyakit jantung sianotik, disseminated intravascular coagulopathy, atau kateterisasi arteri umbilikalis). Hampir 20\% kasus disebabkan oleh kelainan susunan saraf pusat, atau koartasio aorta. ${ }^{9,10,11}$ Pada anak, penyebab hipertensi krisis yang paling sering adalah penyakit renoparenkim dan renovaskular. ${ }^{13,14}$ Penyebab hipertensi pada anak adalah:2,13,15

1. Penyakit parenkim ginjal:

a. Glomerulonefritis:

- Glomerulonefritis akut pasca infeksi

- Nefropati IgA

- Glomerulonefritis membranoproliferatif

- Rapidly progressive (crescentic) glomerulonephritis

- Glomerulosklerosis fokal segmental

b. Vaskulitis sistemik dengan keterlibatan ginjal

- Purpura Henoch - Schoenlein

- Lupus eritematosus sistemik

- Poliarteritis nodosum

c. Sindrom hemolitik uremik

d. Nefritis interstitialis (pielonefritis kronik)

e. Penyakit herediter

f. Anomali ginjal kongenital :

- Refluks vesikoureter (RVU)

- Uropati obstruktif

- Ginjal multikistik displasia (multicyctic dysplastic kidney)

- Horseshoe kidney

- Hipoplasi segmental (Ask-Upmark kidney)

2. Penyakit renovaskular

a. Penyakit arteri renal intrinsik

- Displasia fibromuskular

- Arteritis (Penyakit Kawasaki, Takayasu, Moyamoya)

- Stenosis arteri renalis transplant

- Newborn with umbilical vessel catheters

- Trombosis arteri atau vena renalis ginjal transplant

- Trauma ginjal

b. Kompresi ekstrinsik

- Neoplasma: tumorWilm's, neuroblastoma, feokromositoma, paraganglioma, neurofibroma, limfoma

- Hematoma perirenal, trauma

- Fibrosis retroperitoneal
3. Kardiovaskular
a. Koartasio aorta
b. Middle aortic syndrome
c. Sindrom Williams
d. Sindrom Turner

4. Abnormalitas endokrin
a. Tumor yang mensekresi vasoactive substance (katekholamin, renin)
b. Kelainan tiroid
c. Sindrom Cushing
d. Hiperaldosteronism
e. Congenital adrenal hyperplasia
f. Hiperkalsemia

5. Penyebab lainnya

a. Kelainan neurologik

- Peningkatan tekanan intrakranial

- Kejang, status epileptikus

- Disautonomi familial

b. Cyclic vomiting syndrome

c. Polistemia, terapi eritropoietin rekombinan

d. Obat anestesi : ketamin, naloxon

e. Drug abuse: kokain, amfetamin, metamfetamin, fensiklidin, metilfenidat

\section{Patofisiologi}

Tekanan darah terjadi sebagai manifestasi fungsi curah jantung (cardiac output) dan resistensi perifer. Peningkatan curah jantung akan menyebabkan peningkatan isi sekuncup (stroke volume) dan denyut jantung yang akan menyebabkan peningkatan tekanan darah. Ada beberapa mekanisme terjadinya hipertensi krisis. ${ }^{2,8,9,11}$

\section{a. Sistem renin angiotensin}

Renin diproduksi di aparatus juxtaglomerulus ginjal yang akan mengubah angiotensinogen menjadi dekapeptida angiotensin I, dan kemudian enzim konverting angiotensin (ACE) akan mengubah angiotensin I menjadi angiotensin II yang menyebabkan hipertensi melalui beberapa mekanisme. Angiotensin II merupakan vaskonstriktor poten melalui ikatan dengan angiotensin II receptor I (AT I). Ikatan ini akan menimbulkan berbagai proses yang menyebabkan hipertensi, seperti retensi natrium, hipertrofi sel vaskular, dan menginduksi berbagai jalur proinflamatori dan profibrotik. Angiotensin II juga 
menginduksi sintesis aldosteron di zona glomerulosa adrenal. Aldosteron akan menyebabkan retensi natrium dan ekskresi kalium dan meningkatkan tekanan darah. Angiotensin II juga berikatan dengan reseptor AT II yang menimbulkan efek yang berbeda dengan AT I, yaitu vasodilatasi dan natriuresis yang akan menurunkan tekanan darah. ${ }^{2}$

\section{b. Overload cairan}

Overload cairan merupakan mekanisme yang paling sering menyebabkan hipertensi pada anak dengan penyakit ginjal. Peningkatan produksi aldosteron yang bergantung pada renin serta retensi natrium yang distimulasi oleh A II juga turut berperan. ${ }^{2}$

\section{c. Stimulasi simpatetik}

Stimulasi sistem saraf simpatetik dapat menyebabkan hipertensi berat seperti pada feokromositoma dan neuroblastoma yang menghasilkan zat vasoaktif kateholamin. Aktivasi sistem saraf simpatetik akan menyebabkan vasokonstriksi sistemik. Selain katekolamin, vasoaktif endotelin juga berperan dalam terjadinya hipertensi. ${ }^{2}$

\section{d. Disfungsi endotel}

Endotel mempunyai peran yang sangat penting dalam terjadinya hipertensi krisis. Angiotensin II berperan terhadap dinding pembuluh darah dan dapat menyebabkan disfungsi endotel berupa berkurangnya kemampuan vasodilatasi dan berkurangnya zat proinflamatori maupun profibrotik. Faktor lain yang turut berperan dalam penurunan kemampuan vasodilatasi adalah berkurangnya nitric oxide. Selain itu AT II akan memediasi berbagai faktor transkripsi seperti NF-kB, yang dapat merangsang produksi berbagai sitokin seperti interleukin dan tumor necrosis factor- $\alpha$ serta kemokin dan molekul adhesi vaskular, yang dapat menyebabkan hipertensi.2

\section{e. Obat-obatan}

Beberapa obat seperti amfetamin, kokain, fensiklidin dapat menyebabkan hipertensi melalui mekanisme overstimulasi simpatetik. Kortikosteroid dan calcineurin inhibitor juga dapat menyebabkan hipertensi. Obat dapat juga menyebabkan hipertensi melalui mekanisme overload cairan, aktivasi sistem renin angiotensin, dan vasokonstriksi arteriol aferen glomerulus. ${ }^{2}$

\section{Manifestasi klinik}

Manifestasi klinis dapat terjadi dalam waktu 12 jam hingga 2 hari setelah peningkatan tekanan darah mendadak. ${ }^{1,2,5,12}$ Manifestasi klinis bervariasi tergantung pada kelainan organ target, mulai dari yang asimtomatik sampai yang berat. Manifestasi klinis dapat berupa sakit kepala berat, kejang, gangguan kesadaran, dan gangguan penglihatan. Sering terjadi nausea dan vomitus. ${ }^{1,2,8,14}$ Gangguan penglihatan dapat disebabkan edema dan perdarahan retina, dapat berupa penglihatan kabur hingga buta kortikal.2,10,16 Pemeriksaan funduskopi dilakukan untuk mengetahui ada tidaknya edema papil atau perdarahan retina. Edema papil ditemukan pada 35 persen, dan tidak adanya edema papil tidak menyingkirkan kemungkinan hipertensi ensefalopati. ${ }^{12,14}$ Gangguan ginjal dapat ditandai dengan edema, oliguria, hematuria, dan penurunan fungsi ginjal. Manifestasi klinis lain dapat terlihat sebagai gagal jantung atau edema paru. Hipertensi ensefalopati ditandai dengan penurunan kesadaran dapat berupa apatis, iritabilitas, dan somnolen. ${ }^{10}$ Kejang ditemukan pada $92 \%$ pasien, dapat berupa kejang umum atau fokal. ${ }^{1,12,14}$ Hipertensi ensefalopati yang berat ditandai dengan koma, berdarahan intrakranial, dan kelainan neurologik lainnya. ${ }^{1,2,8,14}$ Dapat ditemukan tanda-tanda gagal jantung seperti dispnu, peningkatan tekanan vena jugularis, takikardia, kelainan pada elektrokardiografi maupun pemeriksaan lainnya. ${ }^{1,2,8,14}$

\section{Tata laksana}

Tujuan pengobatan hipertensi krisis adalah memperbaiki fungsi organ vital dengan mempertahankan perfusi serta menghindarkan komplikasi. Tata laksana hipertensi krisis terdiri dari pemberian antihipertensi onset cepat, mengatasi kelainan organ target (otak, jantung, retina), mencari dan menanggulangi penyebab hipertensi, serta terapi suportif. ${ }^{2}$

\section{a. Obat antihipertensi}

Prinsip tata laksana hipertensi krisis adalah menurunkan tekanan darah secepatnya untuk mencegah 
kerusakan organ target. Li dan Wong (2004) menyusun strategi tata laksana hipertensi emergensi sebagai berikut,

Hitung perbedaan antara tekanan darah pasien tersebut dengan tekanan darah pada persentil 95 untuk pasien tersebut.

Turunkan tekanan darah 25\%-30\% dalam 6 jam pertama, dan selanjutnya 25\%-30\% dalam 36 jam, dan kemudian selebihnya dalam 48-72 jam. ${ }^{17}$ Obat antihipertensi yang digunakan bersifat short acting, parenteral, dan mudah dititrasi. Pada umumnya obat yang digunakan adalah labetalol, nitroprusid, nikardipin, dan fenoldopam. Pasien sebaiknya dirawat di ruangan yang dapat memonitor jantung secara terus menerus. Tekanan darah diukur sekurang-kurangnya setiap 15 menit dan bila mungkin terus-menerus. Sebaiknya dipasang dua jalur infus, satu untuk pemberian obat antihipertensi dan satu lagi untuk pemberian cairan garam salin jika tiba-tiba tekanan darah turun. ${ }^{17}$ Di Departemen Ilmu Kesehatan Anak FKUI-RSCM, hipertensi krisis diobati dengan pemberian infus klonidin atau nifedipin sublingual. ${ }^{2}$ Penurunan mean arterial pressure yang cepat harus dihindari karena dapat menimbulkan berkurangnya aliran darah ke otak dan menyebabkan infark korteks serebri, batang otak, atau retina, dapat juga menyebabkan buta transient atau menetap maupun hemi- atau paraplegia. Selain itu dapat terjadi iskemik pada jantung dan ginjal. ${ }^{1,2}$ Pada hipertensi krisis karena feokromositoma, obat utama adalah $\alpha$-blocker seperti phentolamin intravena atau fenoxybenzamin oral. Pada hipertensi krisis karena kelainan intrakranial, hipertensi mungkin merupakan mekanisme kompensasi untuk mempertahankan perfusi otak dan biasanya tekanan darah tidak diturunkan. ${ }^{2,17}$ Pada hipertensi urgensi, pada umumnya manifestasi klinis tidak berat, dapat berupa nyeri kepala, muntah, tetapi progresif menjadi hipertensi emergensi bila tidak diturunkan dalam waktu 12 hingga 24 jam. Untuk tata laksana hipertensi urgensi, tekanan darah diturunkan lebih lambat yaitu 25\% dalam waktu 12-24 jam, dengan obat antihipertensi parenteral dan oral. ${ }^{17}$

\section{b. Mengatasi kelainan organ target}

Evaluasi terhadap kerusakan organ target sangat penting untuk mendeteksi kelainan otak, jantung, mata, dan ginjal. ${ }^{2,15}$ Jika ditemukan kelainan, maka tata laksana disesuaikan dengan kelainannya. ${ }^{1}$

\section{c. Mencari penyebab dan menanggulanginya}

Pemeriksaan diagnostik dasar pada hipertensi adalah mencari penyebab, ko-morbiditas, dan kerusakan organ target. Meskipun sebagian besar hipertensi pada anak dan remaja bersifat sekunder, tetapi mencari penyebab perlu dilakukan secara individu. Sebagian besar penyebab hipertensi pada anak adalah kelainan renoparenkim dan renovaskular, sehingga pemeriksaan pertama dilakukan terhadap keadaan ini. Kadangkadang diperlukan beberapa pemeriksaan untuk mengetahui penyebab hipertensi seperti plasma renin activity, venyl mandelic acid (VMA) dan kateholamin plasma dan urin, skintigrafi DMSA (dimercaptosuccinic acid), renal vascular imaging, CT-scan atau MRI (magnetic resonance imaging), dan sebagainya. ${ }^{15}$

\section{d. Tata laksana suportif}

Salah satu tata laksana hipertensi adalah restriksi garam. National High Blood Pressure Education Program Working Group (2004) merekomendasikan asupan natrium per hari $1,2 \mathrm{~g}(53 \mathrm{mmol} / \mathrm{hari}$; yang ekuivalen dengan 3,1 g garam) untuk anak usia 4 hingga 8 tahun, dan $1,5 \mathrm{~g} \mathrm{(65} \mathrm{mmol/hari,} \mathrm{ekuivalen} \mathrm{dengan} \mathrm{asupan} \mathrm{3,8}$ g garam) untuk anak yang lebih tua. ${ }^{5}$ Selain pembatasan garam, diperlukan terapi suportif lainnya termasuk dukungan keluarga. ${ }^{17}$

\section{Obat antihipertensi untuk hipertensi krisis}

Berbagai obat antihipertensi telah digunakan dalam tata laksana hipertensi krisis. Dalam kepustakaan, antihipertensi yang sering digunakan adalah labetalol, nikardipin, natrium nitroprusid, diazoksida, hidralazin, fenoldopam, klonidin. Di Indonesia, antihipertensi yang sering digunakan untuk tata laksana hipertensi krisis pada anak adalah klonidin, nifedipin, natrium nitroprusid, dan nikardipin.

\section{Nitroprusid}

Natrium nitroprusid merupakan donor nitric oxide yang menimbulkan vasodilatasi langsung terhadap otot polos vena dan arteriol. Natrium nitroprusid diberikan dengan infus, dimulai dengan dosis $0.3 \mu \mathrm{g} / \mathrm{kg} /$ menit, dan dititrasi sampai tercapai tekanan darah yang diinginkan dengan dosis maximum $8 \mu \mathrm{g} / \mathrm{kg} / \mathrm{menit}$. 
Karena onset dan metabolismenya cepat, pemberian nitroprusid memerlukan monitoring tekanan darah yang kontiniu.

Jika tekanan darah tidak dapat dikontrol dengan nitroprusid $8 \mu \mathrm{g} / \mathrm{kg} /$ menit, maka diperlukan pemberian obat lain seperti labetalol, calcium-channel antagonist, atau diuretik. ${ }^{1,2}$ Penting untuk memonitor kadar sianida darah pada pemakaian lama ( $>72 \mathrm{jam})$, karena pada pemakaian nitroprusid yang lama akan menimbulkan produksi metabolik toksik sianida dan tiosianat, yang akan tertimbun pada pasien dengan gagal ginjal dan gagal hati. Pada pasien yang membutuhkan pengobatan lebih dari 24 jam, direkomendasikan pemberian infus tiosulfat (rasio nitroprusid : tiosulfat $=10: 1$ ) untuk mengeliminasi toksisitas sianida. Gejala klinis toksisitas sianida/tiosianat antara lain anxietas, nyeri kepala, pusing, kebingungan, kaku dagu, kejang, asidosis metabolik, hipoksemia, hipotensi, methemoglobinemia, hipotiroidism, tinitus, gangguan penglihatan, dan takifilaksis. Nitroprusid tidak boleh diberikan pada peningkatan tekanan intrakranial, dan hati-hati pada pasien koartasio aorta. ${ }^{1,2}$ Obat ini harus dilindungi dari sinar matahari. ${ }^{2,17}$

\section{Diazoxid}

Diazoxid, suatu tiazida nondiuretik, merupakan vasodilator arteriol poten, namun mekanisme kerjanya belum jelas. Obat ini hanya dapat diberikan parenteral, mekanisme kerjanya cepat tetapi onset aksinya sulit diprediksi. Dosisnya 1 hingga $3 \mathrm{mg} / \mathrm{kg}$ per dosis secara infus intravena selama 5 hingga 10 menit, dapat diberikan setiap 10 hingga 15 menit hingga responnya terlihat, dengan dosis maximum $10 \mathrm{mg} / \mathrm{kg}$ atau 150 mg per hari..$^{1,2}$

Diazoxid dapat menyebabkan retensi natrium sehingga perlu dikombinasi dengan diuretik seperti furosemid. ${ }^{2,18}$ Efek samping diazoxid sama dengan vasodilator sistemik lainnya. Efek samping lainnya antara lain hiperglikemia, hiperurikemia, mual, muntah, konstipasi, hipertrikosis, skin rash, demam, leukopenia dan trombositopenia. Meskipun diazoxid yang diberikan secara infus lambat dapat ditoleransi dengan baik sama seperti nitroprusid, namun diazoxid sering digantikan oleh labetalol dan nikardipin yang lebih aman dan lebih ditoleransi. Diazoxid tidak boleh diberikan pada pasien dengan perdarahan intraserebral, dissecting aortic aneurysm, infark miokard akut, dan koartasio aorta. ${ }^{1,2}$

\section{Nikardipin}

Nikardipin merupakan calcium channel blockers, bekerja sebagai vasodilator direk dengan menghambat kontraksi otot polos vaskular dengan intervensi calcium influx selular. Obat bekerja dengan cepat, aman, dan efektif dalam menurunkan tekanan darah dengan pemberian infus dosis 0,5 hingga $5,0 \mu \mathrm{g} / \mathrm{kg} /$ menit (maximum $=5 \mathrm{mg} / \mathrm{jam}$ ), dapat digunakan sebagai alternatif terhadap nitroprusid atau labetalol. Efek samping nikardipin antara lain takikardia, nyeri kepala, flushing, pusing sebagai akibat vasodilatasi akut. Nikardipin tidak boleh diberikan pada trauma kepala dan perdarahan intrakranial. ${ }^{1,2,17}$

\section{Klonidin}

Klonidin merupakan obat antihipertensi yang bekerja sebagai agonis sentral. ${ }^{9} 13$ Klonidin bekerja melalui susunan saraf pusat dan menyebabkan penurunan outflow saraf simpatetik dan mengurangi resistensi vaskular perifer dan jantung. Dapat digunakan sebagai obat sekunder pada pasien dengan peningkatan aktivitas saraf simpatetik. Pada pasien yang tidak toleran dengan $\beta$-blocker, klonidin dapat digunakan untuk mencegah vasodilatasi perifer. Obat ini dapat digunakan jika fasilitas monitoring intensif tidak tersedia. ${ }^{2,17,18}$ Efek samping klonidin dapat berupa drowsiness, peningkatan enzim hepar, nyeri otot atau sendi, ruam kulit, dan penurunan kesadaran sehingga jika digunakan pada hipertensi ensefalopati, sering kesulitan untuk mengevaluasi perjalanan penyakitnya. ${ }^{18}$ Jika klonidin tiba-tiba dihentikan, dapat terjadi rebound hypertension. ${ }^{1,3}$

Di Departemen IKA FKUI-RSCM, hipertensi krisis diterapi dengan klonidin drip dan furosemid. Klonidin diberikan per infus dengan dosis $0,002 \mathrm{mg} /$ $\mathrm{kg} / 8 \mathrm{jam}$ dimasukkan dalam $100 \mathrm{ml}$ dextrose 5\% (12 tetes per menit), dan kemudian dosis dinaikkan setiap 30 menit hingga tekanan darah diastolik di bawah $100 \mathrm{mmHg}$. Klonidin dapat dinaikkan hingga dosis maximum $0,006 \mathrm{mg} / \mathrm{kg} 8$ jam (36 tetes per menit). Furosemid diberikan $1 \mathrm{mg} / \mathrm{kg} / \mathrm{dosis}, 2$ kali sehari. Jika tekanan darah diastolik belum mencapai < $100 \mathrm{mmHg}$, tambahkan kaptopril 0,3 mg/kg/dosis. ${ }^{3}$

\section{Nifedipin}

Nifedipin merupakan calcium-channel blockers, yang bekerja sebagai vasodilator langsung dengan 
menghambat kontraksi otot polos vaskular oleh interfensi calcium influx selular, menyebabkan dilatasi arteriol perifer. Nifedipin diberikan secara sublingual 0,25 hingga $0,5 \mathrm{mg} / \mathrm{kg}$ dan efektif dalam 10 menit dengan puncak efek terlihat 30 hingga 40 menit setelah pemberian. ${ }^{14,19,20}$ Nifedipin dapat juga diberikan per oral, namun absorbsi secara sublingual lebih cepat $10-15$ menit dibandingkan dengan secara oral. ${ }^{18}$ Di Departemen IKA FKUI-RSCM, hipertensi krisis diterapi dengan nifedipin sublingual dan furosemid. Nifedipin diberikan dengan dosis $0,1 \mathrm{mg} / \mathrm{kg} /$ dosis, dan kemudian dosis dinaikkan setiap 30 menit hingga tekanan darah diastolik di bawah $100 \mathrm{mmHg}$. Nifedipin dapat dinaikkan hingga dosis maksimum $10 \mathrm{mg} /$ dosis. Furosemid diberikan $1 \mathrm{mg} / \mathrm{kg} / \mathrm{dosis}$, 2 kali sehari. Jika tekanan darah diastolik belum mencapai < $100 \mathrm{mmHg}$, tambahkan kaptopril $0,3 \mathrm{mg} / \mathrm{kg} /$ dosis. ${ }^{3}$ Efek samping nifedipin antara lain nyeri kepala, flushing, pusing, dan takikardia sebagai akibat vasodilatasi akut. .,3,17,19,20 $^{2}$

\section{Hidralazin}

Hidralazin akan menginduksi relaksasi otot polos vaskular yang menyebabkan vasodilatasi arteriol. Obat ini bersifat short half-life dan agar dapat efektif sebagai terapi membutuhkan dosis multipel per hari. Jika diberikan sendirian, hidralazin dapat menimbulkan takikardia, peningkatan aktivitas renin plasma, retensi natrium. Hidralazin lebih baik digunakan bersama diuretik dan $\beta$-blocker. ${ }^{2,18}$ Hidralazin diberikan IV bolus atau IM dengan dosis $0,2-0,5 \mathrm{mg} / \mathrm{kg} /$ dosis setiap 4-6 jam (max. 3,5 mg/kg/hari). ${ }^{1}$ Efek samping hidralazin antara lain nyeri kepala, palpitasi, berkeringat, nausea, dan pusing. Pemberian dosis tinggi (>200 mg/hari) dapat menimbulkan lupus-like syndrome, tetapi gejala ini reversibel dan sangat jarang menyebabkan kelainan ginjal. ${ }^{2,18}$

\section{Labetalol}

Labetalol adalah antihipertensi yang mempunyai kombinasi efek $\beta$-blocker atau $\beta$-adrenergic antagonis dengan peripheral $\alpha$-adrenergic antagonism yang menyebabkan vasodilatasi vaskulatur perifer dan efek antihipertensi sinergistik. Sebagai $\beta$-blocker, labetalol menurunkan tekanan darah melalui penurunan denyut jantung dan kontraktilitas miokard, serta mengurangi curah jantung (cardiac output). ${ }^{2,18}$ Labetalol dapat diberikan secara intravena dengan dosis $0,2-1,0 \mathrm{mg} / \mathrm{kg} /$ dosis diberikan selama 2 menit. Jika tidak ada respon, dapat diberikan lagi setiap 5-10 menit dengan dosis maximum $60 \mathrm{mg}$, atau $0,25-2,0 \mathrm{mg} / \mathrm{kg} / \mathrm{jam}$ secara infus intravena terus menerus. ${ }^{1,2}$

Efek samping $\beta$-adrenergic antagonist antara lain, kardiovaskular: bradikardia, SSP: nyeri kepala, ataksia, pusing, sinkop, ngantuk, iritabilitas, gangguan pendengaran dan penglihatan, mimpi buruk, kelemahan, lekas capek, depresi. Saluran cerna: nausea, diare, konstipasi. Hematologi: eosinofilia, leukopenia, trombositopenia. Impotensi genitourinaria. ${ }^{1}$

Sebagai $\beta$-adrenergic antagonist, labetalol dapat menurunkan kontraktilitas miokard, sehingga tidak dapat digunakan pada gagal jantung kongestif. Sebagai $\beta$-adrenergic antagonist, labetalol tidak boleh diberikan pada asma. ${ }^{1,2,18}$ Labetalol juga tidak dapat diberikan pada pasien diabetes melitus dependen insulin karena dapat menyebabkan hipoglikemik. ${ }^{8}$

\section{Fenoldopam}

Fenoldopam merupakan dopamine $D-1$ receptor agonist, yang juga berikatan dengan $\alpha 2$-adrenoreceptor. Obat ini diberikan dengan dosis $0,5-2 \mu \mathrm{g} / \mathrm{kg} /$ menit. Fenoldopam kontraindikasi untuk glaukoma dan dapat menyebabkan nyeri kepala dan takikardia. ${ }^{2,17}$

\section{Esmolol}

Esmolol merupakan antihipertensi yang jarang digunakan pada anak. Esmolol bekerja sebagai cardioselective adrenoreceptive $\beta$-blocker, yang diberikan dengan infus intravena secara bolus dengan dosis $100-500 \mu \mathrm{g} / \mathrm{kg}$ selama 1-2 menit dan kemudian 50-500 $\mu \mathrm{g} / \mathrm{kg} /$ menit. $^{1,2}$

\section{Enalaprilat}

Enalaprilat merupakan $A C E$ inhibitor yang diberikan secara intravena dengan dosis $0,005-0,01 \mathrm{mg} / \mathrm{kg} /$ dosis setiap 8-24 jam hingga 1,25 mg/dosis. ${ }^{2,18}$ Obat ini menurunkan tekanan darah dalam 30 menit dan tetap dependen renin. ${ }^{2}$

\section{Isradipin}

Isradipin merupakan dihidropiridin generasi kedua, suatu calcium channel antagonist. Onsetnya cepat, biasanya tekanan darah turun dalam 1 jam, dengan puncak efek dalam 2-3 jam. ${ }^{2}$ 


\section{Minoxidil}

Minoxidil merupakan vasodilator direk seperti diazoxid, dengan membuka channel kalium pada sel otot polos, mengakibatkan potassium efflux dan menyebabkan hiperpolarisasi dan relaksasi. Obat ini terutama bekerja pada arteriol dan tidak menyebabkan dilatasi vena. Umumnya efek timbul dalam satu menit dan menghilang dalam 8-12 jam. ${ }^{2}$

\section{Clevidipin}

Clevidipin adalah dihidropiridin ultra-short-acting, suatu calcium channel antagonist. Clevidipin akan menurunkan tekanan darah dalam waktu dua menit setelah pemberian infus dan efeknya cepat hilang setelah dihentikan. ${ }^{2}$

\section{Urapidil}

Urapidil merupakan antagonis $\alpha$-adrenoreceptor postsinaptik perifer dengan efek agonis sentral terhadap serotonin 5-HT receptors. Obat ini menurunkan tekanan darah dengan cara menurunkan resistensi perifer. Obat ini diberikan secara intravena dan efeknya sama dengan enalaprilat, nitroprusid, dan hidralazin. ${ }^{2}$

\section{Penutup}

Hipertensi krisis potensial mengancam jiwa sehingga memerlukan penanganan yang agresif untuk menurunkan tekanan darah. Penanganan hipertensi krisis memerlukan obat antihipertensi yang bekerja cepat sehingga dapat mencegah kerusakan organ target

Tabel 1: Daftar obat untuk hipertensi krisis ${ }^{1,2,17}$

\begin{tabular}{|c|c|c|c|}
\hline Obat & Jenis & Dosis & Cara pemberian \\
\hline $\mathrm{Na}$ nitroprusid & Vasodilator & $0,3-0,8 \mu \mathrm{g} / \mathrm{kg} / \mathrm{menit}$ & IV $^{*}$ infus \\
\hline Diazoxid & Vasodilator & $\begin{array}{l}1-3 \mathrm{mg} / \mathrm{kg} \text { selama } 5-10 \text { menit } \\
\text { (max. }=150 \text { menit })\end{array}$ & IV infus \\
\hline Nikardipin & Ca channel blocker & $\begin{array}{l}0,5-5 \mu \mathrm{g} / \mathrm{kg} / \mathrm{menit}(\max .5 \mathrm{mg} / \\
\text { jam) }\end{array}$ & IV infus \\
\hline Klonidin & $\alpha$-agonist sentral & $\begin{array}{l}0,002 \mathrm{mg} / \mathrm{kg} / 8 \text { jam dan dapat } \\
\text { dinaikkan hingga dosis max. } 0.006 \\
\mathrm{mg} / \mathrm{kg} / 8 \text { jam. }\end{array}$ & IV infus \\
\hline Nifedipin & Ca channel blocker & $\begin{array}{l}0,1 \mathrm{mg} / \mathrm{kg} / \text { dosis dapat dinaikkan } \\
\text { hingga dosis max. } 10 \mathrm{mg} / \text { dosis }\end{array}$ & Sublingual \\
\hline Hidralazin & Vasodilator & $\begin{array}{l}0,2-0,5 \mathrm{mg} / \mathrm{kg} / \mathrm{dosis} \text { setiap } 4-6 \text { jam } \\
\text { (max. } 3,5 \mathrm{mg} / \mathrm{kg} / \mathrm{hari} \text { ) }\end{array}$ & IV bolus, IM** \\
\hline Labetalol & $\alpha \& \beta$-blocker & $\begin{array}{l}\text { Infus: } 0,25-3 \mathrm{mg} / \mathrm{kg} / \mathrm{jam} \text {; atau } \\
\text { Bolus: } 0,2-1 \mathrm{mg} / \mathrm{kb} / \text { dosis. Jika tdk } \\
\text { ada respons, boleh re-dosis setiap }\end{array}$ & $\begin{array}{l}\text { IV infus (lebih } \\
\text { disukai) }\end{array}$ \\
\hline Fenoldopam & $\begin{array}{l}\text { Dopamine } 1 \text { receptor } \\
\text { agonist }\end{array}$ & $\begin{array}{l}\text { 5-10 menit, dinaikkan hingga } \\
\text { max. } 40 \mathrm{mg} / \text { dosis }\end{array}$ & IV infus \\
\hline Esmolol & $\begin{array}{l}\text { Cardioselective } \\
\text { adrenoreceptive } \\
\beta \text {-blocker }\end{array}$ & $\begin{array}{l}0,5-2 \mu \mathrm{g} / \mathrm{kg} / \mathrm{menit} \\
\text { Bolus: } 100-500 \mu \mathrm{g} / \mathrm{kg} \text { selama } 1-2 \\
\text { menit, kemudian } 50-500 \mu \mathrm{g} / \mathrm{kg} / \\
\text { min }\end{array}$ & IV infus \\
\hline Enalaprilat & ACE inhibitor & $\begin{array}{l}0,005-0,01 \mathrm{mg} / \mathrm{kg} / \text { dosis setiap } \\
8-24 \text { jam hingga } 1,25 \mathrm{mg} / \text { dosis }\end{array}$ & IV bolus \\
\hline Isradipin & Ca channel blocker & $\begin{array}{l}0,05-0,1 \mathrm{mg} / \mathrm{kg} / \text { dosis hingga } 5 \\
\mathrm{mg} / \text { dosis }\end{array}$ & Per oral \\
\hline Minoxidil & Direct vasodilator & $\begin{array}{l}0,1-0,2 \mathrm{mg} / \mathrm{kg} / \text { dosis hingga } 10 \\
\mathrm{mg} / \mathrm{dosis}\end{array}$ & Per oral \\
\hline
\end{tabular}

Keterangan: ${ }^{*} \mathrm{IV}=$ intravena, ${ }^{* *} \mathrm{IM}=$ intra muskular 
yang lebih berat. Selain menurunkan tekanan darah, tindakan lain adalah mencari penyebab hipertensi dan menanggulanginya.

\section{Daftar pustaka}

1. Vogt BA, Davis ID. Treatment of hypertension. Dalam: Avner ED, Harmon WE, Niaudet P, penyunting. Pediatric Nephrology. Edisi ke-5. Philadelphia: Lippincott Williams \& Wilkins;2004.h.1199-220.

2. Flynn JT, Tullus K. Severe hypertension in children and adolescents: pathophysiology and treatment. Pediatr Nephrol 2009;24:1101-12.

3. Alatas H. Ensefalopati hipertensi. Naskah simposium dan workshop sehari: Kegawatan pada penyakit ginjal anak. Makasar: 27-28 Mei, 2006,17-28.

4. Task Force on Blood Pressure Control in Children. Report of the second task force on blood pressure in children1987. Pediatrics 1987;79:1-25.

5. National High Blood Pressure Education Program Working Group on High Blood Pressure in Children and Adolescents. The fourth report on the diagnosis, evaluation, and treatment of high blood pressure in children and adolescents. Pediatrics 2004;114:555-76.

6. Scharer K. Hypertension in children. Pediatr Nephrol 1987;1:50-8.

7. The Joint National Committee on Detection, Evaluation, and Treatment of High Blood Pressure: The 1984 report of the Joint National Committee. Archs Intern Med 1984;144:1045-57.

8. Kher KK. Hypertension. Dalam: Kher KK, Makker SP, penyunting, Clinical Pediatric Nephrology. Edisi ke-1. New York: McGraw-Hill, Inc; 1992.h.323-76.

9. Dillon MJ. Hypertension. Dalam: Postlethwaite RJ, penyunting. Clinical Paediatric Nephrology. Edisi ke-2, Oxford: Butterworth Heinemann; 1994.h.175-95.

10. Nolan CR. Malignant hypertension and other hypertensive crisis. Dalam: Schrier RW, penyunting. Disease of the Kidney and Urinary Tract. Edisi ke-7, Philadelphia:
Lipincott Williams \& Wilkins; 2001.h.1513-92.

11. Goonasekera CDA, Dillon MJ. The child with hypertension. Dalam: Webb N, Postlethwaite R, penyunting. Clinical Pediatric Nephrology. Edisi ke-3, Oxford: Oxford University Press; 2003.h.151-61.

12. Rust RS, Chun RWM. Interrelationships between renal and neurologic diseases and therapies. Dalam: Swaiman KF, Ashwal S, Ferriero DM, penyunting. Pediatric Neurology, Principles \& Practice. Edisi ke-4, Philadelphia: Mosby Elsevier; 2006.h.2233-83.

13. Brewer ED. Evaluation of hypertension in childhood diseases. Dalam: Avner ED, Harmon WE, Niaudet P, penyunting. Pediatric Nephrology, edisi ke-5, Philadelphia: Lippincott Williams \& Wilkins; 2004. h.1179-97.

14. Polinsky MS. Neurologic manifestations of renal disease. Dalam: Berg BO, penyunting. Principles of Child Neurology. Edisi ke-1. New York: McGraw-Hill; 1996.h.1327-41.

15. Leung LC. Hypertension: diagnosis and evaluation. Dalam: Chiu MC, Yap HK, penyunting. Practical Paediatric Nephrology. Edisi ke-1. Hong Kong: Medcom Limited; 2005.h.80-8.

16. Cooney MJ, Bradley WG, Symko SC, Patel ST, Groncy PK. Hypertensive encephalopathy: Complication in children treated for myeloproliferative disorders- Report of three cases. Radiology 2000;214:711-6.

17. Li SPS, Wong SN. Treatment of hypertension. Dalam: Chiu MC, Yap HK, penyunting. Practical Paediatric Nephrology. Edisi ke-1. Hong Kong: Medcom Limited; 2005.h.89-95.

18. Brazy PC. Therapy of hypertension. Dalam: Greenberg A, Cheung AK, Falk RJ, Coffman TM, Jennette JC, penyunting. Primer on Kideny Diseases. Edisi ke-1. San Diego: Academic Press; 1994.h. 355-61.

19. Gauthier B, Trachtman H. Short acting nifedipine. Pediatr Nephrol 1997;11:786-7.

20. Egger DW, Deming DD, Hamada N, Perkin RM, Sahney S. Evaluation of the safety of short-acting nifedipine in children with hypertension. Pediatr Nephrol 2002;17: $35-40$ 